\title{
Financing through the conversion of physical properties into securities: Juridical- Economic Study
}

\author{
Mahmoud Bahmani \\ PhD Candidate Research Institute of Shakhes Pajouh, Isfahan,Iran \\ Email: Mahmoud.Bahmani1326@gmail.com
}

\begin{abstract}
The classical bond structure is based on the interest. On the other hand, in Islamic financial system charging interest is forbidden, therefore, bonds cannot continue to be issued and exchanged. As a consequence, we have to follow a structure that can be replaced or reissued with bonds for the purpose of avoiding usury (Riba). For the implementation of monetary policy, Sukuk (Islamic bonds) as one of the instruments of securitization is considered to be the most important financial instrument in Islamic financial system. This instrument has been issued by the Islamic governments and companies during recent years.

In fact, companies convert their assets into securities through Sukuk issuance and by selling Sukuk, they can obtain cash capital. The question here is whether, the financial instrument of Sukuk is consistent with the principles of Shiite. There has also been question as to whether financing through this method is possible for financial institutions as a new instrument in modern marketing. In order to answer the above-mentioned questions, first, we have considered the financing mechanism through Sukuk issuance from the theoretical and applicable aspects in order to comment on its acceptability from the legal and financial terms. In the present research, firstly, the method of financing through Sukuk issuance is fully described, and subsequently, the validity of the process according to the Shiite jurisprudence principles is explained. The results of this research show an acceptable and successful implementation of Sukuk instrument, so that they meet the three main criteria of legality, efficiency and acceptability.
\end{abstract}

Keywords: Sukuk, ljarah Sukuk (Leasing/ Rent Sukuk), Islamic Financing, Islamic Bonds, Musharakah Sukuk (Participation Sukuk), Usury Free Banking, Islamic Banking

\section{Council for Innovative Research}

Peer Review Research Publishing System

Journal: International Journal Of Management \& Information Technology

Vol . 10, No 8

editorsijmit@gmail.com

www.ijmit.com 


\section{Introduction}

\section{1) Problem Statement}

The development of Islamic capital market infrastructures and institutional infrastructures is undoubtedly an essential matter and in order to attract more investments, there is a need to formulate rules and regulations with regard to the particular and different circumstances of Islamic and non-Islamic countries. The most obvious instrument of financing in Islamic capital market is called Sukuk (Islamic bonds) which has different varieties. The new patterns of Sukuk are constantly entered into the financial markets of Islamic and non-Islamic countries as well as banks. On the other hand, the development and expansion of financial markets depends on capability of these markets to attract different investor's resources and also optimal transmission of these resources into their clients. This will contribute to the economic growth of society and also will fulfill the expectations of both groups. In recent years, an increasing volume of transactions and business activities has intensified the need to create a method of financing which is in accordance with the Islamic tenets.

As a result, according to the importance of Islamic bonds (Sukuk), the main issue of the present research is to what extent the financial instrument of Sukuk can operate successfully as a new instrument in the economic environment of Iran and also as a new product in the field of bank marketing? It is worth noticing here that in addition to the complete analysis of different types of Sukuk, ljarah Sukuk (Leasing/ Rent Sukuk) which has recently been considered in Iran is also investigated and analyzed through this research.

\section{2) Research Importance}

The present research is important for the following reasons:

1. Iran's monetary and financial market (e.g. including banks) is poor in the field of development of various financial instruments; therefore, the need for modern banking services marketing is very significant.

2. The major instrument that has been used in Iran since $70^{\text {th }}$ is called bond. This instrument has not been accountable to the variety of existing needs.

3. Defining, explaining and describing of Sukuk instrument as one of the new financial instruments that it operates in accordance with the Islamic banking is momentous.

4. Providing operational solutions/guidelines for effective use of Sukuk can be considered as the main reason of conducting this research.

\section{3) Theoretical Background}

\section{3-1) Introduction}

The classical bond structure is based on the interest. On the other hand, in Islamic financial system charging interest is forbidden, therefore, bonds cannot continue to be issued and exchanged. As a consequence, we have to follow a structure that can be replaced or reissued with bonds for the purpose of avoiding usury (Riba). For the implementation of monetary policy, Sukuk as one of the instruments of securitization is considered to be the most important financial instrument in Islamic financial system. This instrument has been issued by the Islamic governments and companies during recent years. In fact, companies convert their assets into securities through Sukuk issuance and by selling Sukuk, they can gain cash capital.

\section{3-2) Bond Definition}

In finance, a bond is an instrument of indebtedness of the bond issuer to the holders. It is a debt security, under which the issuer owes the holders a debt and, depending on the terms of the bond, is obliged to pay them interest (the coupon) and/or to repay the principal at a later date, termed the maturity date. Owners of bond are debt holders, or creditors, of the issuer. In addition, bond issuance is considered as one of the methods of financing. Bonds can be issued in the form of nameless (without a named holder) or named (with a named holder) and collateral or without collateral.

\section{3-2-1) Advantages and Disadvantages of Bonds}

\section{3-2-1-1) Advantages}

Bonds have clear advantages over other securities. They are as follows:

For the issuer agency (firm): their effective low-cost as well as their repurchasing capability;

For the buyer: their capability of transmission and fixed-interest.

Totally, bonds are attractive because of the comparative certainty of a fixed interest payment twice a year and a fixed lump sum at maturity. Since fixed-income, interest-bearing bonds are not permissible in Islam, Sukuk securities are structured to comply with the Islamic law and its investment principles, which prohibit the charging of and/or paying interest. 


\section{3-2-1-2) Disadvantages}

The most important disadvantage of bonds for issuer as well as buyer is the firms' risk of bankruptcy due to its inability to repay the principal and the interest. In other words, issuers could default on their interest and principal repayment obligations if they run into cash-flow problems. In some Islamic countries, especially Iran, where the law of usury free banking has been applied, the nature and implementation of bond is generally rejected.

\section{3-4) Islamic Securities Characteristics}

Ownership of Securities Holders

Most of Islamic securities have obvious differences from usury securities from the ownership aspect.

Quality of Profit Distribution

The interest of Islamic securities relates to the type of contract that securities are issued based on that and also they are different from the expected or fixed interest rate. Islamic securities can be divided into three main groups. They are as follows:

- Securities on the basis of buying and selling of Dayn

- Securities on the basis of buying and selling of physical properties

- Securities on the basis of participation in the profit of economic plans

-

\section{3-4-1) Functions of Islamic Financial Instruments}

- The best way of providing capital for projects and huge economic activities

- It is a very good solution for investors who are seeking to invest their surplus financial resources.

- An excellent way of managing liquidity, Islamic banks and financial institutions

- An appropriate instrument for risk management and uncertainty

- An appropriate instrument for fairly distribution of wealth and income

\section{3-5) Participation Securities as an alternative to Bonds}

- Participation securities are bonds issued in accordance with the Islamic banking law. The legal nature of these securities can be analyzed on the basis of civil partnership contract.

- In the participation system which has different types, savings owner provides whole or part of capital required for the economic entity (instead of taking advantage of lending and charging interest), and through an agreement with employer, participates in loss and profit. At the end of each financial period, after costs deduction, obtained profit will be divided according to the ratios that were agreed in the contract between the capital owner and economic factor (employer).

- Participation securities are usually caused variable profits and since they are based on Mozarebeh or Participation, so they do not guarantee fixed profit. As a result, according to the definition of participation securities, it seems that bonds' religious problems do not exist for participation securities.

\section{3-5-1) Characteristics of Participation Securities in Iran}

Participation securities are issued in accordance with the Islamic principles and they are based on investment in economic projects with positive rate of return. The profit will be divided between investors and issuer (who is responsible for the project completion).

For each case, issuer must guarantee a minimum level of obtainable profit from the related project.

Securities should be used to finance specific projects and cannot be used elsewhere.

Other features of participation securities like bonds are conventional.

\section{3-5-2) Disadvantages of Participation Securities}

The lack of private sector interest in participation securities can be caused by many factors such as: their high cost, companies are required to guarantee the principal payment and the interest in exchange for issuance of participation securities prior to the maturity date, no transaction should take place based on the real rate of return on investment.

Bonds can only be redeemed at maturity date, and prior to the maturity date bond has only the ability of trading in the secondary market, but participation securities can be purchased at any time. 


\section{Sukuk}

Sukuk (plural of sakk) are referred to as "Islamic bonds" but the correct translation of the Arabic word of Sukuk is, "Islamic Investment Certificates". Under Sukuk structure, the Sukuk holders (investors) each hold an undivided beneficial ownership in the "Sukuk assets". These Sukuk represent the proportional ownership of an existing asset or a pool of diversified assets, and a pledge against existing or future cash flows generated from these assets for a specified period of time. The risk and return associated with underlying assets and these cash flows are passed to Sukuk holders. These assets may be tangible or intangible, existing or described with deferred delivery, usufruct or services. Under Sukuk structure the investors, Sukuk holders each hold an undivided beneficial ownership in the underlying assets. In fact, companies convert their assets into securities through Sukuk issuance and by selling Sukuk, they can obtain cash capital.

\section{3-6-1) Types of Sukuk}

Generally, Sukuk can be divided into two categories: Government Sukuk and Corporate Sukuk. But according to the Accounting and Auditing Organization of Islamic Financial Institutions (AAOIFI), different types of investment Sukuk are as follows:

\section{- Sukuk of ljarah (Leasing)/ Rent Sukuk}

ljarah is a contract in which lessee is the owner of the benefits of a specified asset in a specified period of time for the fund paid to the lessor and is divided into regular ljarah and ljarah Al-muntahiyah Bi-ttamlik. In regular ljarah, the specified asset shall be returned to the lessor after the specified period but in ljarah Al-muntahiyah Bi-ttamlik the lessor, according to a condition stated in the contract, shall change the ownership of the asset for the benefit of the lessee.

\section{- Normally Securities of Rent}

In these securities, the financial institution rents capital goods and consumer durables relative to the life of the lease for any period of time. Institution at the end of the contract, the goods were delivered in the depreciated commodities market (second hand) sells and the price of the sale to buy a new or account holders of the securities deposited.

\section{- Rent Securities in Condition of Hiring}

In this method the financial institution using sources of the transferable securities of financial institutions with the rental, purchase goods or capital goods and consumer durables as the hire-purchase grant applicants. The tenant by paying the last rent of owner gets like tenant.

\section{- Sukuk of Murabahah}

Sukuk of Murabahah is securities that their own are as joint financial assets (religious) based on the Murabahah contract. These securities have a fixed output and are salable in the secondary market. Murabaha securities is designed for a variety of securities, including securities Murabaha financing to provide liquidity, capital formation and securities firms, commercial banks and leasing Murabaha mortgage to convert receivables into securities that went on Murabaha mortgage banks and securities of financial firms.

\section{- Mortgage ljarah Sukuk}

Here, issuer collects the investors' funds by issuing ljarah Sukuk, then buys those assets which the originator (bank or leasing company) has transferred to the government, firms or families, in form of ljarah Al muntahi Bi-ttamlik, on behalf of the investors. Originator undertakes to collect all rentals of the assets from the lessees on specified maturity dates and pay them to the owners of securities via an investment bank. Owners of securities can either wait until maturity date or sell their own securities in the secondary market.

\section{- Sukuk of Istisnaa}

Istisnaa derived from the source of creation, means making the request. By Istisnaa it is meant buying something that is produced according to the customer's order. Istisnaa contract or agreement means that the person making the order and ask him to come to the craftsman who builds some of the goods which he brought to the property. This is a contract signed between the two is that the owner of the industry, good for him to build consensus and get the agreed amount. Therefore, Sukuk of Istisnaa, documents and certificates have the same value and are used to gather the funds necessary to build a product that is owned by Sukuk holders. Sukuk of Istisnaa publisher is producing goods. Subscription is purchased the product in question and the funds collected the cost of goods.

\section{- Sukuk of Participation (Musharakah Sukuk)}

Sukuk of participation, documentation and certificates with a value equal to the aggregate initial funds for new projects, expansion of existing projects or financing business is based on participation. Sukuk holders in the amount of its share of contributions, or plan assets are owned. Sukuk secondary markets can be traded partnership agreement. The only difference between the two Sukuk of Mudaraba and Sukuk is very similar partnership and the partnership, the relationship between issuer and holder of the Sukuk. Unlike Sukuk of Mudaraba and Sukuk rate of participation such as "HP", "Rent" and "Istisnaa" that returns are constant, variable. 


\section{- Sukuk of Mozarebeh}

Mozarebeh securities are securities that are designed base on contract of Mozarebeh. Partnership with the transferable securities issuer, securities, funds, applicants to the collection, profitable economic activities (trade) at the end of each accounting period the profits based on written papers, divided among his papers themselves and owners of securities. Owner and holder of securities of the issuer's operating partnership agreement.

\section{- Sukuk of Joaleh}

Joaleh securities are securities, joint ownership of assets (labor, service or goods) and delivered based on contract of Joaleh end of the operation (presented by this agreement), the owners of the securities, joint ownership will result. Action may result service or physical assets.

\section{- Derivative Securities}

Usually takes the form of an agreement to buy or sell an asset or item (commodity, property, security) at a fixed price on or before a certain date. Derivative securities are traded on exchanges like other financial instruments, and their value varies with the value of the underlying assets (which are traded separately from the derivatives). Futures contracts, forward contracts, options and swaps are some common types of derivatives used in hedging or to gain leverage. Also called contingent claim since the payoff from a derivative is dependent upon whether or not some event occurs.

\section{3-6-2) Sukuk Issuance in Iran}

The Accounting and Auditing Organization of Islamic Financial Institutions (AAOIFI) defines Sukuk as certificates of equal value that represent proportion ownership of an existing asset or a pool of diversified assets, and a pledge against existing or future cash flow from these assets, for a specified periods of time, where the risk and return associated with cash flows generated by the underlying assets pass Sukuk holders. There are several types of Sukuk, but AAOIFI have been introduced 14 types. In addition, among several types of Sukuk, Leasing (Rent) Sukuk, Sukuk of Mozarebeh and Sukuk of Istisnaa have greater importance. These types of Sukuk are most commonly used.

\section{3-6-3) Leasing Sukuk Specifications}

- There is no time limit with respect to the lease. The lease contract can be continued until there is an asset. As a result, Sukuk of ljarah can be defined in three different terms including: short-term, medium-term and long-term.

- There is no need to pay the lease/rent in cash, but any commodity or financial asset can be paid as the lease/rent through mutual agreement between the parties. This interesting feature of lease contract opens a bright future facing financial policies. Because instead of profit, Sukuk can be changed into stock according to mutual agreement between the parties and fixed/certain process. This issue is more important and significant for those companies that are willing to give over part of their assets for the purpose of financing.

\section{3-6-4) Financing Method Using Leasing Sukuk}

Issuer collects the investors' funds and buys the originator's required asset from the producer (seller) in cash and on behalf of the investors, then leases the asset to the originator in form of a regular ljarah or an ljarah $\mathrm{Al}-\mathrm{muntahi} \mathrm{Bi}$ ttamlik. Originator undertakes to pay the rentals to the owners of securities via an investment bank on certain maturity dates. Issuer, at the end of the regular ljarah, gets back the underlying asset and sells it in the used assets market on behalf of the investors, than changes its ownership to the lessee. The owners of securities can either wait until maturity and receive the rentals or sell their securities in the secondary market.

The primary market for this kind of ljarah Sukuk is a combination of wakalah contract, cash selling, regular ljarah, or ljarah Al-muntahi Bi-ttamlik. Issuer collects the funds, buys the originator's required commodity in cash, and then leases it to the originator in form of a regular ljarah contract or an ljarah Al-muntahi Bi-ttamlik contract. The secondary market for these securities is the selling a portion of joint ownership of the leased asset however, has far as Islamic jurisprudential point of view is concerned, wakalah, cash selling, regular ljarah, ljarah Al-muntahi Bi-ttamlik, and selling a portion of joint ownership of the leased asset contract are permissible.

\section{3-6-5) Ijarah Sukuk versus Bonds}

- They represent a claim on ownership of asset and cash flow as opposed to conventional bonds whose claim is on debt instrument.

- Their return is expected/estimated from underlying asset as opposed to conventional bonds whose return (interest) is pre-determined.

- They provide periodic stream of income (similar to conventional bonds).

- There is a possibility of capital appreciation, that is, investors can get more return on their invested capital, as opposed to conventional bonds that return is fixed and cannot vary with the performance of bond issuer. 
- Their return on invested capital is not guaranteed as opposed to conventional bonds that the issuer is obligated to pay at maturity.

- Their contract is based on seller-buyer relationship as opposed to the borrower-lender.

- Assets may be tangible or intangible, existing or described with deferred delivery, usufruct, or services a non-existing asset similar to bonds.

- Sukuk may have fixed or variable rates of return as opposed to a fixed rate in conventional bonds.

\section{4) Research Objectives}

1. Identifying and explaining different types of Sukuk and their characteristics

2. Studying different limitations of using Sukuk instrument in Iran

3. Studying and explaining different factors of success or failure in Iran with emphasis on Leasing Sukuk

4. Providing operational guidelines/solutions for effective and efficient use of Sukuk with emphasis on leasing Sukuk

5. Defining and studying the impact of leasing Sukuk in the process of financing

6. Defining and using of Sukuk as a new financial instrument instead of bond in the country's banking system

\section{5) Research Hypotheses}

\section{5-1) Main Hypothesis}

7. The financial instrument of Sukuk can have successful implementation in the economic environment of Iran.

\section{5-2) Secondary Hypotheses}

- Different types of Sukuk are in accordance with the law of usury free banking.

- Sukuk are efficient from the economical aspect.

- Sukuk get attention of people, banks and economic firms/enterprises.

\section{6) Research Results}

When a new financial instrument is introduced in a particular economic environment, it needs to meet some factors for success. These factors are as follows:

- Legality;

- Efficiency; and

- Acceptability.

To see whether ljarah Sukuk could be operating successfully and be used as an appropriate financial instrument, the above-mentioned factors should be studied.

\section{6-1) First hypothesis: Different types of Sukuk are in accordance with the law of usury free banking.}

Is leasing Sukuk in accordance with the law of usury free banking? As it was described in the previous sections, Sukuk are issued without any doubt of usury being used in them and are in accordance with the law of usury free banking as well as religion. Thus, Sukuk are certainly in accordance with the law of usury free banking and as a result the hypothesis is confirmed.

\section{6-2) Second hypothesis: Sukuk is economically efficient.}

There has also been question as to whether Sukuk are economically efficient. This question can be studied from different aspects. First, Sukuk can be considered as an efficient instrument to control liquidity. The Central Bank can buy and sell issued Sukuk by the government in open market operations. It seems that Sukuk issuance are more appropriate in compare with participation securities issuance, because Sukuk have not high liquidity and therefore are more efficient instrument to control liquidity. The Central Bank cannot issue Sukuk itself and it can only buy and sell government Sukuk.

Sukuk can be an effective instrument for investment. Sukuk price behavior differs from conventional bonds. So if they placed in an investment portfolio, because of both diversity and different price behaviors, reduce risk. This issue gets attention of all investors. Sukuk is an appropriate and available instrument to steer wandering liquidity of society toward productive investment. So we can claim that Sukuk are economically efficient. That is particularly true for leasing Sukuk.

\section{Third hypothesis: Sukuk get attention of people, banks and economic firms/enterprises.}

The question can be raised whether Sukuk get attention of people and economic enterprises. With regard to their high efficiency, certainty of profit and liquidity in the secondary market and also no doubt in their religious aspect, these securities are get attention of public, especially micro risk-averse investors. 
While Sukuk and conventional bonds have the capability of ranking by the international ranking institutions, therefore, they have the capability of issuance in international markets.

\section{Results}

1. Sukuk is a new, tested and appropriate instrument for the process of financing of public/ governmental and private companies.

2. Sukuk can be considered as a supplement or a replacement instrument instead of participation securities in order to control liquidity.

3. Sukuk is a legal, acceptable and efficient instrument which has the possibility of using in Iran, although they are in need of providing the following infrastructures:

1. Standardization of assets used in Sukuk and their evaluation process

2. Facilitating the issuance and ranking of Sukuk and creating ranking institutions

3. Creating a secondary market for buying and selling of Sukuk and facilitating their liquidity

So the government can take an important step toward the law of usury free banking through a proper planning and preparing for the use of new financial instruments. In addition, using this new financial instrument can resolve many of the financing problems of economic enterprises.

\section{References}

1. Masoud Behdadfar, Ali mohammadi, Mohsen Mirzaie. 2014. "Introducing New Islamic Financial Instruments (Sukuk) (With an Emphasis on Housing and Construction Sector)". International Journal of Basic Sciences and Applied Research, 3(SP): 133-143.

2. Kordvani, Amir. 2009. "A legal analysis of the Islamic bonds (sukuk) in Iran". International Journal of Islamic and Middle Eastern Finance and Management, 2(4): 323-337.

3. Mohammadi, Zakyeh. 2013. "Studying the Status of the Interest Free Loan Regarding Non-Usury Banking Law in Islamic Republic of Iran". Journal of Applied Environmental and Biological Sciences, 3(8): 61-68.

4. Afshar, Tahmoures. 2013. "Compare and Contrast Sukuk (Islamic Bonds) with Conventional Bonds, Are they Compatible?". Journal of Global Business Management, 9 (1): 44-52.

5. http://en.wikipedia.org/wiki/Bond_\%28finance\%29

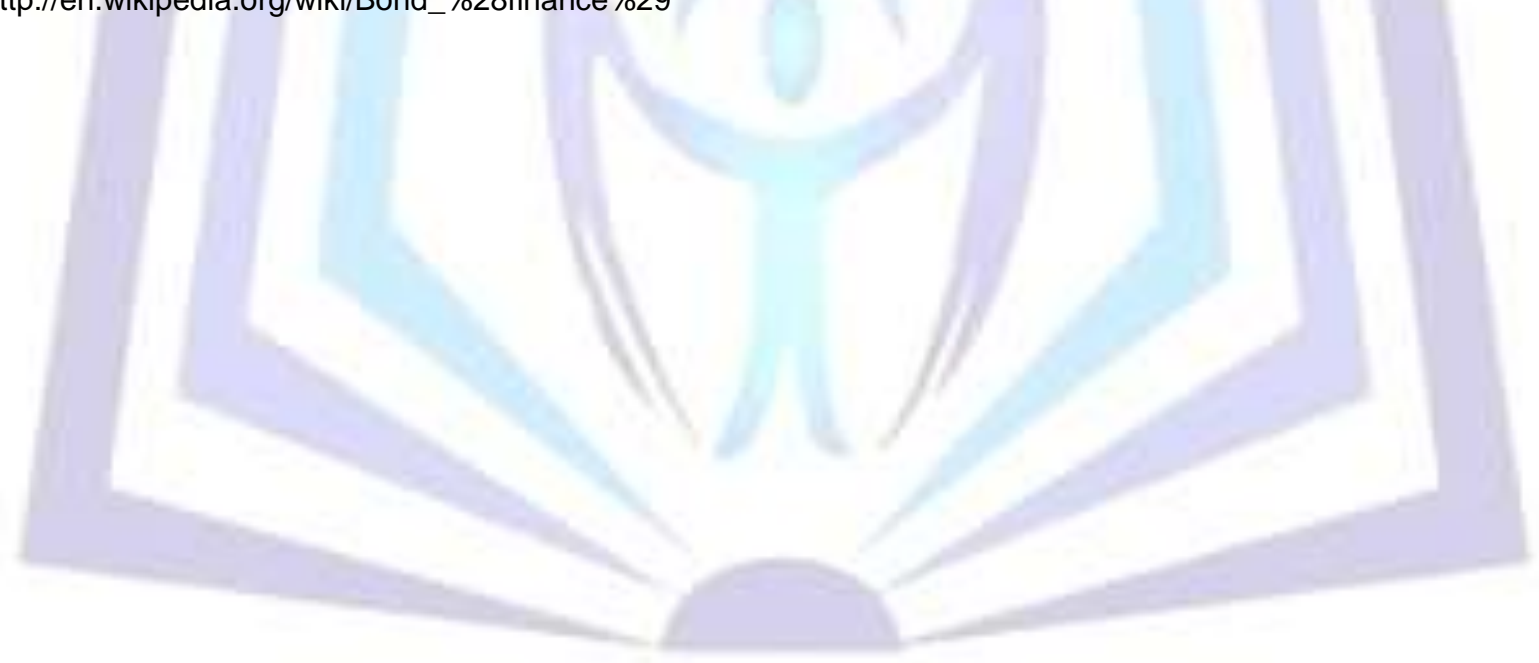

